\title{
Genetic and epigenetic alterations of human chromosome 3, investigated by NotI-microarrays in seven types of epithelial cancers
}

\author{
G. V. Gerashchenko ${ }^{1}$, V. V. Gordiyuk ${ }^{1}$, V. I. Kashuba ${ }^{1,2}$ \\ ${ }^{1}$ Institute of Molecular Biology and Genetics, NAS of Ukraine \\ 150, Akademika Zabolotnoho Str., Kyiv, Ukraine, 03143 \\ ${ }^{2}$ Karolinska Institute, \\ Stockholm SE-17177, Sweden \\ g.v.gerashchenko@imbg.org.ua
}

\begin{abstract}
Aim. To identify common and specific genetic/epigenetic changes of human chromosome 3, using the data of NotI-microarrays in seven types of epithelial cancers. Methods. We used descriptive statistics for the comparative analysis of NotI-microarray data from seven types of epithelial cancers. Results. The analysis of the NotI-microarrays showed significant changes (deletion or methylation) in 74 genes/loci in seven different epithelial cancers, namely colorectal, ovarian, renal, lung, breast, cervical and prostate. Five genes from the 3p14-3p24 region (FOXP1, LRRC3B, NKiRAS1, RBSP3, ZIC4) were altered in all cancer types. For fifteen genes deletion/methylation was found in a majority of tumors. For example, ITGA9, GORASP1, IQSEC1, CGGBP1, NBEAL2 and VHL are localized in the 3p12-3p26 region; PPP2R3A, FGF12, ALDH1L1, GATA2 and PLCL2 are localized on the 3q13-3q28 region. Twenty-two genes out of 74 studied showed alterations specific for a single type of tumor. The largest number, 13 genes/loci was found in the prostate cancer. This suggests specific mechanisms of prostate cancer development. Conclusions. NotI-microarrays for human chromosome 3 allowed to identify several common genetic/epigenetic alterations and also tumor-specific changes in seven types of epithelial cancer.
\end{abstract}

Ke y w o r d s: NotI-microarray, colorectal cancer, ovarian cancer, renal cancer, lung cancer, cervical cancer, breast cancer, prostate cancer, TSG, methylation, deletion, human chromosome 3.

\section{Introduction}

E. Zabarovsky and V. Kashuba groups investigated genetic/epigenetic alterations in human cancers by a large-scale method, named the NotI-microarray, for more than fifteen years.
This method represents a comparative genome hybridization technology (Karolinska Institute International Patent WO02/086163 and PCT/ SE02/00788 [1]), based on hybridization of the NotI-linking libraries, produced from tumor and normal genomic DNA [2]. It makes

(C) 2018 G. V. Gerashchenko et al.; Published by the Institute of Molecular Biology and Genetics, NAS of Ukraine on behalf of Biopolymers and Cell. This is an Open Access article distributed under the terms of the Creative Commons Attribution License (http://creativecommons.org/licenses/by/4.0/), which permits unrestricted reuse, distribution, and reproduction in any medium, provided the original work is properly cited 
possible, to determine both, the genetic (deletions, amplifications) and epigenetic (methylation, demethylation) changes in the genomic DNA of the NotI-linked genes / loci, due to the sensitivity of the NotI restriction enzyme to a methylation status of $\mathrm{CpG}$ islands. Using this technology, 181 NotI-linking clones from different regions of human chromosome 3 were analyzed in more, than 250 malignant tumor samples, derived from different organs and tissues. $[2,3]$. It is known that genetic and epigenetic disturbances of chromosome 3 have very important influence on carcinogenesis of different human cancers [4-6]. On chromosome 3 several well-known and putative tumor suppressor genes (TSG) as well as many cancer-associated genes are situated [3-7]. The 3 p25-p26 region is harboring the well-known TSG, such as $V H L ; 3 p 12-p 14.2$ region contains the FHIT gene; $3 \mathrm{p} 24$ possesses the RARB gene and 3p21-p22 region includes the RASSF1A gene $[8,9]$. However, a function and a role of many other genes of chromosome 3 , which show alterations in different human cancer types, were largely unknown, before the NotImicroarray study.

The aim of the present work is to identify common and specific genetic/epigenetic changes of human chromosome 3 , using the data of NotI-microarrays in seven types of epithelial cancer.

\section{Materials and Methods}

We have performed comparative analysis of the NotI-microarray data for 7 types of epithelial cancers [2, 10-18] using methods of descriptive statistics. Fisher's exact test and Chisquare criteria were used for analysis of methylation and/or deletion frequencies in groups of tumors with different patho-morphological characteristics $[2,10-18]$. The cases with $p$ value below 0.05 were considered statistically significant. The Benjamini-Hochberg procedure with false discovery rate (FDR) 0.20 was used to correct p-value under multiple comparisons detection [19].

\section{Results and Discussion}

We have reviewed and summarized the data from different cohorts and with different data calculations for colorectal, ovarian, renal, lung, breast, cervical and prostate cancers $[2,10$ 18]. All the data represent epithelial tumors, investigated by NotI-microarrays. A fragment of NotI-microarray data is shown in Figure 1.

Notably, the greatest number of alterations is hetero- and homozygous deletions or methylation, in all reported data sets. Amplifications and demethylation were quite a rare event in epithelial tumors in comparison with leukemia [20]. Hence, deletions and methylation were in the focus of the present paper. Altogether, we found that 74 genes / loci of chromosome 3 exhibited significant changes in seven types of epithelial tumors. These results are presented in Table 1. It was found 40 genes/ loci with changes from $3 p$ arm and 34 genes/ loci from $3 \mathrm{q}$ arm of chromosome 3. Five genes, namely FOXP1, LRRC3B, NKIRAS1, RBSP3 and ZIC4 altered in all seven studied tumor types. They are located in the 3p14-3p24 region.

Five genes/loci, namely ITGA9, GORASP1, IQSEC1, CGGBPI and PPP $2 R 3 A$, showed genetic /epigenetic changes in six various types of tumor. Ten genes/loci - WNT7A, NBEAL2, VHL, LOC285205, FGF12, ALDH1L1, GATA2, PLCL2, ABHD5/TOPAZ1, EPHB1 - had genetic /epigenetic alterations in five cancer types. 


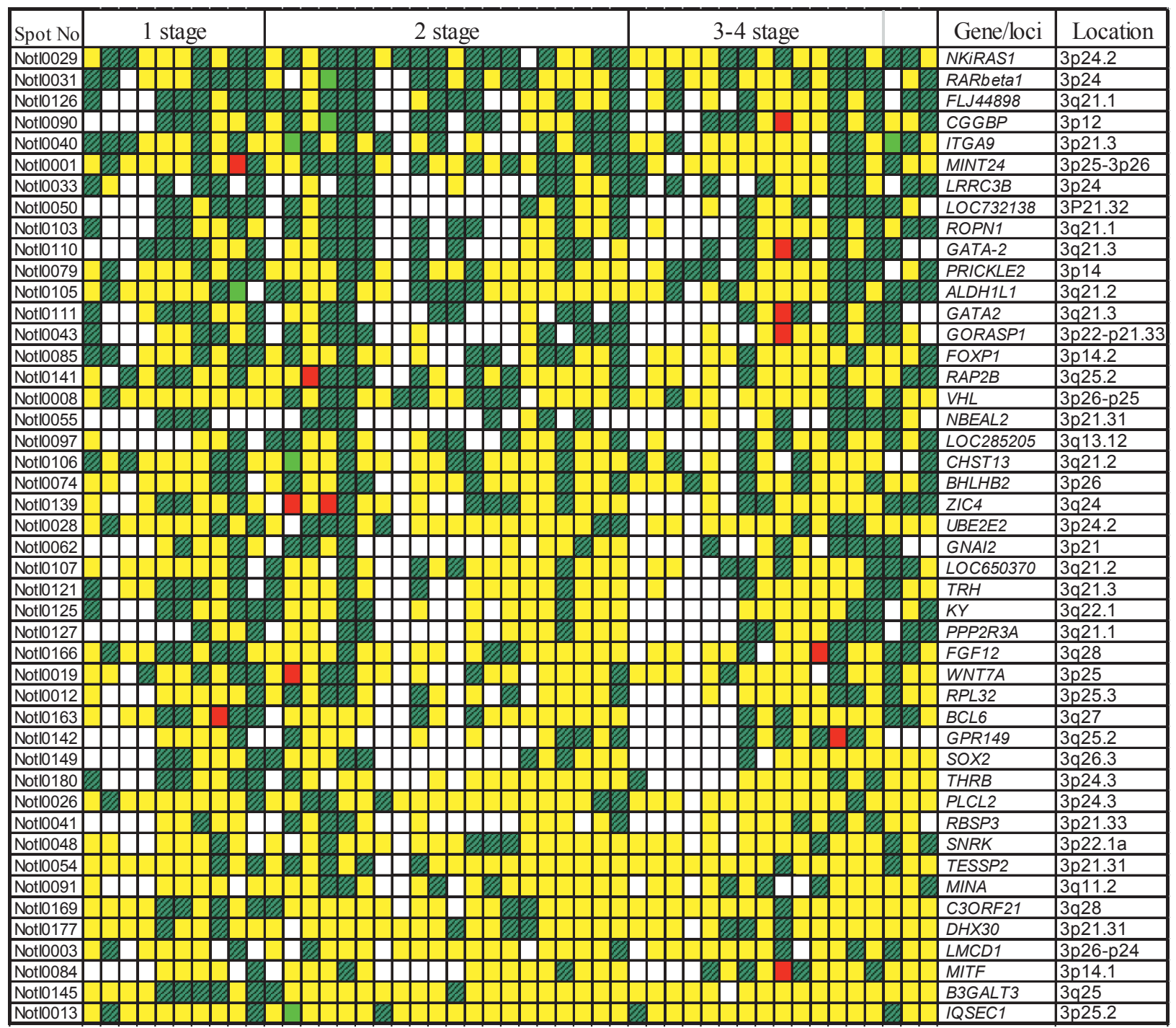

Fig. 1. A fragment of NotI-microarray data in breast tumors. Green and dark green with hatching squares: methylation/ deletion $(<0.85)$, red: amplification/demethylation $(>1.5)$, yellow: unchanged $(>0.85,<1.5)$, and white: no info. (grey and dark grey with hatching squares: methylation/deletion $(<0.85)$, black: amplification/demethylation $(>1.5)$, light grey: unchanged $(>0.85,<1.5)$, and white: no info)

Genes GORASP1, IQSEC1, CGGBP1, NBEAL2 and $V H L$ are localized in the 3p12-3p26 region; genes PPP2R3A, FGF12, ALDH1L1, GATA2 and $P L C L 2$ are situated in the $3 \mathrm{q} 13-3 \mathrm{q} 28$ region. A large number of genes with the same changes in different epithelial tumors suggests the common mechanisms of cancer development and the function of these genes as putative tumor suppressor genes.

Twenty-two genes out of 74 have alterations only in the single type of tumor. The major part of them (13 genes / loci) is found in pros- 
Table 1. Genes and loci of chromosome 3 with changes (deletion/methylation) in seven types of epithelial cancers

\begin{tabular}{|c|c|c|c|c|c|c|c|c|c|c|}
\hline № & $\begin{array}{c}\text { Number of } \\
\text { localiza- } \\
\text { tions }\end{array}$ & Gene/locus & Location & OC & ColC & BC & CervC & LC & $\operatorname{ccRCC}$ & PC \\
\hline 1 & 2 & 3 & & 5 & 6 & 7 & 8 & 9 & 10 & 11 \\
\hline 1 & 7 & FOXP1 & $3 \mathrm{p} 13$ & $*$ & $*$ & $*$ & $\%$ & $*$ & $\%$ & $\%$ \\
\hline 2 & 7 & $L R R C 3 B$ & $3 \mathrm{p} 24.1$ & $*$ & $*$ & $*$ & $*$ & $*$ & $*$ & $\%$ \\
\hline 3 & 7 & NKIRAS1 & $3 \mathrm{p} 24.2$ & $*$ & $\%$ & $*$ & $\%$ & $*$ & $*$ & $*$ \\
\hline 4 & 7 & RBSP3 (CTDSPL) & $3 \mathrm{p} 22.2$ & $*$ & $\%$ & $*$ & $\%$ & $*$ & $*$ & $\%$ \\
\hline 5 & 7 & ZIC4 & $3 q 24$ & $*$ & $*$ & $*$ & $\%$ & $*$ & $\%$ & $\div$ \\
\hline 6 & 6 & ITGA9 & $3 \mathrm{p} 22.2$ & $*$ & $*$ & $*$ & $*$ & $*$ & & $*$ \\
\hline 7 & 6 & GORASP1 & $3 \mathrm{p} 22.2$ & $*$ & $*$ & & $*$ & $*$ & $*$ & $*$ \\
\hline 8 & 6 & IQSEC1 & 3p25.2-p25.1 & $*$ & $*$ & & $\%$ & $*$ & $*$ & $*$ \\
\hline 9 & 6 & $C G G B P 1$ & $3 p 11.1$ & $*$ & $*$ & $*$ & $*$ & $*$ & & $*$ \\
\hline 10 & 6 & PPP2R3A & $3 q 22.2-q 22.3$ & $*$ & $\%$ & $*$ & $*$ & $*$ & & $*$ \\
\hline 11 & 5 & WNT7A & $3 \mathrm{p} 25.1$ & $*$ & $*$ & & $*$ & $*$ & & $*$ \\
\hline 12 & 5 & NBEAL2 & $3 \mathrm{p} 21.31$ & $*$ & $*$ & & & $*$ & $*$ & $*$ \\
\hline 13 & 5 & VHL & $3 \mathrm{p} 25.3$ & & $*$ & $*$ & $*$ & $*$ & $*$ & \\
\hline 14 & 5 & LOC285205 & $3 \mathrm{p} 13.12$ & $*$ & $*$ & * & & $*$ & & $\%$ \\
\hline 15 & 5 & FGF12 & $3 q 28-q 29$ & $*$ & & $*$ & $*$ & $*$ & & $*$ \\
\hline 16 & 5 & ALDH1L1 & $3 q 21.3$ & & & $*$ & $\%$ & $*$ & $*$ & $\%$ \\
\hline 17 & 5 & GATA2 & $3 q 21.3$ & * & $*$ & $*$ & & $*$ & & $\div$ \\
\hline 18 & 5 & PLCL2 & $3 \mathrm{p} 24.3$ & & $\%$ & & $\%$ & $*$ & $\%$ & $*$ \\
\hline 19 & 5 & ABHD5/TOPAZ1 & $3 \mathrm{p} 21.33 / 3 \mathrm{p} 21.31$ & * & & & $*$ & $*$ & $*$ & $*$ \\
\hline 20 & 5 & EPHB1 & $3 \mathrm{q} 22.2$ & $*$ & & & $*$ & $*$ & $*$ & $*$ \\
\hline 21 & 4 & NUDT16P & $3 q 22.1$ & $*$ & $*$ & & & $*$ & & $*$ \\
\hline 22 & 4 & ROPN1 & $3 q 21.1$ & $*$ & & $*$ & & $*$ & & $*$ \\
\hline 23 & 4 & UBE2E2 & $3 \mathrm{p} 24.3$ & & $*$ & $*$ & $*$ & $*$ & & \\
\hline 24 & 4 & GNAI2 & $3 \mathrm{p} 21.31$ & $*$ & & & & $*$ & $\%$ & $*$ \\
\hline 25 & 4 & PRICKLE2 & $3 \mathrm{p} 14.1$ & * & & & $*$ & * & $*$ & \\
\hline 26 & 4 & RPL32 & $3 \mathrm{p} 25.2$ & & & & $*$ & $*$ & $*$ & $*$ \\
\hline 27 & 4 & THRB & $3 \mathrm{p} 24.2$ & $*$ & $*$ & & $*$ & $*$ & & \\
\hline 28 & 4 & BCL6 & $3 q 27.3$ & 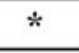 & & $*$ & & $*$ & & $*$ \\
\hline 29 & 4 & BHLHE40 & $3 \mathrm{p} 26.1$ & & & $*$ & $*$ & $*$ & & $*$ \\
\hline 30 & 4 & FGD5 & $3 \mathrm{p} 25.1$ & & & & $*$ & $*$ & $*$ & $*$ \\
\hline 31 & 4 & LRRN1 & $3 \mathrm{p} 26.2$ & * & & & $*$ & $*$ & $*$ & \\
\hline 32 & 3 & FBLN2 & $3 \mathrm{p} 25.1$ & $*$ & & & & $*$ & & $*$ \\
\hline
\end{tabular}


Continued Table 1

\begin{tabular}{|c|c|c|c|c|c|c|c|c|c|c|}
\hline 1 & 2 & 3 & 4 & 5 & 6 & 7 & 8 & 9 & 10 & 11 \\
\hline 33 & 3 & $K Y$ & $3 q 22.2$ & & $*$ & & & $*$ & & $*$ \\
\hline 34 & 3 & РPM1М & $3 \mathrm{p} 21.2$ & $*$ & & & & & $*$ & $*$ \\
\hline 35 & 3 & MINA & $3 q 11.2$ & & & * & & $*$ & & $\%$ \\
\hline 36 & 3 & $T R H$ & $3 q 22.1$ & $*$ & & * & & * & & \\
\hline 37 & 3 & $L O C 285375$ & $3 \mathrm{p} 25.1$ & $*$ & & & $*$ & & & $*$ \\
\hline 38 & 2 & MINT24 & 3 p. 26 & & $*$ & * & & & & \\
\hline 39 & 2 & $R A R B$ & $3 \mathrm{p} 24.2$ & & $*$ & * & & & & \\
\hline 40 & 2 & LOC732138 & 3 p. 21.32 & & $*$ & $*$ & & & & \\
\hline 41 & 2 & GPR149 & $3 q 25.2$ & & & & & * & & $*$ \\
\hline 42 & 2 & LMCD1 & $3 \mathrm{p} 25.3$ & & * & & & * & & \\
\hline 43 & 2 & $R A P 2 B$ & $3 q 25.2$ & & & $*$ & & & & $*$ \\
\hline 44 & 2 & SOX2 & $3 \mathrm{q} 26.33$ & & & $*$ & & & & $*$ \\
\hline 45 & 2 & PAQR9 & $3 \mathrm{q} 23$ & $*$ & & & & * & & \\
\hline 46 & 2 & $L O C 650370$ & $3 q 21.2$ & & $*$ & $*$ & & & & \\
\hline 47 & 2 & CHST13 & $3 q 21.3$ & $*$ & & * & & & & \\
\hline 48 & 2 & SOX14 & $3 q 22.3$ & & & & $*$ & & & $*$ \\
\hline 49 & 2 & ANKRD28 & $3 \mathrm{p} 25.1$ & & $*$ & & & * & & \\
\hline 50 & 2 & FSTL1 & $3 q 13.33$ & & & $*$ & & & & $*$ \\
\hline 51 & 2 & PDZRN3 & $3 \mathrm{p} 13$ & & & & $*$ & & & $*$ \\
\hline 52 & 1 & FL.J44898 & $3 \mathrm{q} 21.1$ & & & $*$ & & & & \\
\hline 53 & 1 & B3GALNT1 & $3 \mathrm{q} 26.1$ & & & & & & & $*$ \\
\hline 54 & 1 & EPHB3 & $3 q 27.1$ & & & & & & & $*$ \\
\hline 55 & 1 & KBTBD8 & $3 \mathrm{p} 14.1$ & & & & & & & $*$ \\
\hline 56 & 1 & LRRC58 & $3 q 13.33$ & & & & & & & $*$ \\
\hline 57 & 1 & PARP3 & $3 \mathrm{p} 21.2$ & & & & & & & $*$ \\
\hline 58 & 1 & TMEM45A & $3 q 12.2$ & & & & & & & * \\
\hline 59 & 1 & ACPL2 (PXYLP1) & $3 q 23$ & & & $*$ & & & & \\
\hline 60 & 1 & СНCHD6/C3orf 46 & $3 q 21.3$ & & & & & & & $*$ \\
\hline 61 & 1 & CKLFSF6 & $3 \mathrm{p} 22.3$ & & $*$ & & & & & \\
\hline 62 & 1 & CLASP2 & $3 \mathrm{p} 22.3$ & & & & & & & * \\
\hline 63 & 1 & СМТМ8 & $3 p 22.3$ & & & & & & & $*$ \\
\hline 64 & 1 & DZIPIL & $3 q 22.3$ & & & & & & & $*$ \\
\hline 65 & 1 & HMGB1L5(Pseudo) & $3 \mathrm{p} 24.3$ & & & & & & & $*$ \\
\hline 66 & 1 & MANF & $3 \mathrm{p} 21.2$ & & & & & & & * \\
\hline 67 & 1 & MITF & $3 \mathrm{p} 13$ & & & & & $*$ & & \\
\hline 68 & 1 & USP19 & $3 \mathrm{p} 21.31$ & & & & & & & $*$ \\
\hline
\end{tabular}


Continued Table 1

\begin{tabular}{|c|c|l|c|c|c|c|c|c|c|c|}
\hline $\mathbf{1}$ & $\mathbf{2}$ & $\mathbf{3}$ & $\mathbf{4}$ & $\mathbf{5}$ & $\mathbf{6}$ & $\mathbf{7}$ & $\mathbf{8}$ & $\mathbf{9}$ & $\mathbf{1 0}$ & $\mathbf{1 1}$ \\
\hline 69 & 1 & MOBP & $3 \mathrm{p} 22.1$ & $*$ & & & & & & \\
\hline 70 & 1 & DCBLD2 & $3 \mathrm{q} 12.1 ; 3$ & $*$ & & & & & & \\
\hline 71 & 1 & FNDC3B & $3 \mathrm{q} 26.31$ & & & $*$ & & & & \\
\hline 72 & 1 & C3ORF21 (XXYLT1) & $3 \mathrm{q} 29$ & & & $*$ & & & & \\
\hline 73 & 1 & DHX30 & $3 \mathrm{p} 21.31$ & & & $*$ & & & & \\
\hline 74 & 1 & ABTB1/PODXL2 & $3 \mathrm{q} 21$ & $*$ & & & & & & \\
\hline
\end{tabular}

Notes: OC — ovarian cancer; ColC — colorectal cancer; BC — breast cancer; CervC — cervical cancer; LC — lung cancer; ccRCC — clear cell renal cell carcinoma; PC — prostate cancer; ${ }^{*}$ — genes / loci with significant differences with $\mathrm{FDR}=0.2$.

tate cancer. This may indicate specific mechanisms of carcinogenesis of the prostate that are different from other localizations.

Noteworthy, earlier many investigations have been focused on studying the genes of the $3 p$ arm of the chromosome $3[2,5,6]$, whereas little attention has been paid to the genes of the $3 \mathrm{q}$ arm. The results of NotImicroarrays show the involvement of $3 \mathrm{q}$ arm genes / loci in the carcinogenesis of epithelial tumors of all seven localizations. For example, the ZIC4 gene encodes the Zic family member 4 that is important in the development.

It participates in the regulation of transcription by RNA-polymerase II, but it has very low expression levels. It has deletion/methylation changes in all seven tumor localization. Our data are confirmed by other researchers on another type of epithelial cancer (bladder cancer) [21]. Importantly, these epigenetic changes could be detected in biological fluids, such as urine, while it is impossible to detect the ZIC4 expression levels.

Another gene from 3q arm with deletion/ methylation changes in 6 tumor localizations is $P P P 2 R 3 A$. This gene encodes one of the regulatory subunits of the protein phosphatase 2, which is implicated in the negative control of cell growth and division [22]. However, the genetic/epigenetic changes of this gene in epithelial cancers were not known until our studies.

Four genes from $3 \mathrm{q}$ arm, which have deletion/methylation in 5 localizations of epithelial tumors are FGF12, ALDH1L1, GATA2, EPHB1. FGF12 is a member of the FGF family which is involved in a variety of biological processes, including cell growth, morphogenesis, tissue repair, tumor growth, and invasion [23]. The methylation of FGF12 in colorectal cancers was shown [24]. Our study has confirmed this type of the FGF12 epigenetic changes in prostate cancer [18]. It is revealed as a putative biomarker in esophageal cancer [25]. The ALDH1L1 gene encodes the aldehyde dehydrogenase 1 family member L1. Loss of function (epigenetic silencing) or expression of ALDH1L1 is associated with increased cell motility, decreased apoptosis and cancer progression [26]. On the other hand, ALDH1L1 is the indicative gene of cancer cell stemness and it is a biomarker in colon cancer, which is associated with worth prognosis [27]. 
GATA2 encodes a member of the GATA family of zinc-finger transcription factors. It conducts transcriptional signals in particular from the androgen receptor [28]. GATA2 has a multifaceted function in prostate cancer aggressiveness and is a highly attractive target for treatments of lethal prostate cancer [29]. The GATA2 expression is associated with poor prognosis in acute myeloid leukemia [30]. The $E P H B 1$ gene encodes a transmembrane protein which is a receptor for ephrin-B1. Loss of the ephrin receptor (EphB1) expression may be associated with aggressive cancer phenotypes in acute myelogenous leukemia [31]. The tumor suppressor function of $E P H B 1$ in breast, colon and lung cancers was shown [32].

Noteworthy, the alterations of many genes (ITGA9, LRRC3B, FGF12, GORASP1, NKIRAS1, CTDSPL (RBSP3), GATA2, SEMA3B, IQSEC1, PPMIM1, PRICLE2, BHLHE40 et al.), which were found by NotImicroarrays, have been confirmed by other methods, such as LOH, MSP, bisulfite sequencing, deletion analysis and expression studies [10-18]. The TSG function for several genes was confirmed in model systems (cell lines, experimental animals), using transient and constitutive expression of these genes [33-35].

Moreover, we have investigated genetic/ epigenetic changes and expression of some genes, which have no NotI-site, from wellknown TSG RASSF 1A 3p21.31 region. We have shown deletion/methylation changes by NotImicroarray in some tumor localization of genes from this region (3p21.31) named NBEAL2, GNAI2, TOPAZ1. Our study has confirmed genetic/epigenetic changes and loss of expression for $G P X 1$ and $S E M A 3 B$ in renal and lung cancers [35-37]. Data of other investigators have revealed the down regulation of HYAL1, HYAL2, RASSF1A (3p21.31 region) in non-small cell lung cancer [34]. These data indicate the multiple inactivation of TSG and potential TSG clusters in human chromosome 3 .

\section{Conclusions}

The analysis of the data, obtained with NotImicroarrays for human chromosome 3 , identified several common genetic/epigenetic alterations in seven types of epithelial cancer and tumor-specific changes as well. These data make a basis for the creation of special sets of markers for early diagnostics, prediction of a course of disease, and evaluation of efficacy and a choice of therapy.

\section{REFERENCES}

1. Zabarovsky ER, Ernberg I, Li J, Protopopov AI, Kashuba VI, Wahlestedt C, Zabarovska VI. Novel methods for high throughput genome analysis and use of these methods for identifying the species composition of complex microbiological systems. International patent application PCT/SE02/00788 with priority date April 20, 2001 (US provisional patent application US60/284925).

2. Zabarovsky ER, Allikmets R, Kholodnyuk I, Zabarovska VI, Paulsson N, Bannikov VM, Kashuba VI, Dean M, Kisselev LL, Klein G. Construction of representative NotI linking libraries specific for the total human genome and for human chromosome 3. Genomics. 1994; 20(2):312-6.

3. Pavlova TV, Kashuba VI, Muravenko OV, Yenamandra SP, Ivanova TA, Zabarovskaia VI, , Rakhmanaliev ER, Petrenko LA, Pronina IV, Loginiv VI, Yurkevich OY, Kisselev LL, Zelenin AV, Zabarovsky ER. Technology of analysis of epigenetic and structural changes of epithelial tumors genome with NotI-microarrays by the example of human chromosome 3. Mol. Biol. 2009; 43(2): 339-347.

4. Gordiyuk $V V$, Kondratov $A G$, Gerashchenko $G V$, Kashuba VI. Novel epigenetic markers of early 
epithelial tumor growth and prognosis. Biopolym. Cell. 2013; 29(3):215-220.

5. Uzawa N, Yoshida MA, Hosoe S, Oshimura M, Amagasa T, Ikeuchi T. Functional evidence for involvement of multiple putative tumor suppressor genes on the short arm of chromosome 3 in human oral squamous cell carcinogenesis. Cancer Genet Cytogenet. 1998; 107(2):125-31.

6. Kok K, Naylor SL, Buys CH. Deletions of the short arm of chromosome 3 in solid tumors and the search for suppressor genes. Adv Cancer Res. 1997; 71:27-92.

7. Zabarovsky ER, Lerman MI, Minna JD. Tumor suppressor genes on chromosome $3 p$ involved in the pathogenesis of lung and other cancers. Oncogene. 2002; 21:6915 -6935.

8. Kuroki T, Trapasso F, Yendamuri S, Matsuyama A, Alder H, Mori M, Croce CM. Allele loss and promoter hypermethylation of VHL, RAR-beta, RASS$F 1 A$, and FHIT tumor suppressor genes on chromosome $3 p$ in esophageal squamous cell carcinoma. Cancer Res. 2003; 63(13):3724-8.

9. Dreijerink K, Braga E, Kuzmin I, Geil L, Duh FM, Angeloni D, Zbar B, Lerman MI, Stanbridge EJ, Minna JD, Protopopov A, Li J, Kashuba V, Klein G, Zabarovsky ER. The candidate tumor suppressor gene, RASSF 1A, from human chromosome $3 \mathrm{p} 21.3$ is involved in kidney tumorigenesis. Proc Natl Acad Sci U S A. 2001; 98(13):7504-9.

10. Gerashchenko GV, Gordiyuk VV, Skrypkina IY, Kvasha SM, Kolesnik OO, Ugryn DD, Pavlova TV, Zabarovsky ER, Rynditch AV, Kashuba VI. Screening of epigenetic and genetic disturbances of human chromosome 3 genes in colorectal cancer. Ukr Biokhim Zh. 2009; 81(4):81-7.

11. Gordiyuk VV, Gerashchenko GV, Skrypkina IYa, Symonchuk OV, Pavlova TV, Ugryn DD, Manzhura EP, Vakulenko GO, Zabarovsky ER, Rynditch AV, Kashuba VI. Identification of chromosome 3 epigenetic and genetic abnormalities and gene expression changes in ovarian cancer. Biopolym. Cell. 2008; 24(4):323-332.

12. Kashuba V, Dmitriev AA, Krasnov GS, Pavlova T, Ignatjev I, Gordiyuk VV, Gerashchenko AV, Braga EA, Yenamandra SP, Lerman M, Senchenko VN, Zabarovsky E. NotI microarrays: novel epigenetic markers for early detection and prognosis of high grade serous ovarian cancer. Int J Mol Sci. 2012; 13(10):13352-77.

13. Dmitriev AA, Rudenko EE, Kudryavtseva AV, Krasnov GS, Gordiyuk VV, Melnikova NV, Stakhovsky EO, Kononenko OA, Pavlova LS, Kondratieva TT, Alekseev BY, Braga EA, Senchenko VN, Kashuba VI. Epigenetic alterations of chromosome 3 revealed by NotI-microarrays in clear cell renal cell carcinoma. Biomed Res Int. 2014; 2014:735292.

14. Dmitriev AA, Kashuba VI, Haraldson K, Senchenko VN, Pavlova TV, Kudryavtseva AV, Anedchenko EA, Krasnov GS, Pronina IV, Loginov VI, Kondratieva TT, Kazubskaya TP, Braga EA, Yenamandra SP, Ignatjev I, Ernberg I, Klein G, Lerman MI, Zabarovsky ER. Genetic and epigenetic analysis of non-small cell lung cancer with NotI-microarrays. Epigenetics. 2012; 7(5):502-13.

15. Senchenko VN, Liu J, Loginov W, Bazov I, Angeloni D, Seryogin Y, Ermilova V, Kazubskaya T, Garkavtseva R, Zabarovska VI, Kashuba VI, Kisselev LL, Minna JD, Lerman MI, Klein G, Braga EA, Zabarovsky ER. Discovery of frequent homozygous deletions in chromosome $3 \mathrm{p} 21.3$ LUCA and AP20 regions in renal, lung and breast carcinomas. Oncogene. 2004; 23(34):5719-28.

16. Kashuba VI, Skripkina IIa, Saraev DV, Gordiiuk VV, Vinnitskaia AB, Tsyba LA, Pogrebnŏ PV, Blinov VM, Zabarovskiǔ ER, Ryndich AV. [Identification of changes in gene loci potentially associated with cervical cancer using NotI microarrays]. Ukr Biokhim Zh. 2006; 78(2):113-20.

17. Senchenko VN, Kisseljova NP, Ivanova TA, Dmitriev AA, Krasnov GS, Kudryavtseva AV, Panasenko GV, Tsitrin EB, Lerman MI, Kisseljov FL, Kashuba VI, Zabarovsky ER. Novel tumor suppressor candidates on chromosome 3 revealed by NotImicroarrays in cervical cancer. Epigenetics. 2013; 8(4):409-20.

18. Dmitriev AA, Rosenberg EE, Krasnov GS, Gerashchenko GV, Gordiyuk VV, Pavlova TV, Kudryavtseva AV, Beniaminov AD, Belova AA, Bondarenko YN, Danilets RO, Glukhov AI, Kondratov AG, Alexeyenko A, Alekseev BY, Klein G, Senchenko VN, Kashuba VI. Identification of Novel Epigenetic 
Markers of Prostate Cancer by NotI-Microarray Analysis. Dis Markers. 2015; 2015:241301.

19. Benjamini Y, Hochberg Y. Controlling the false discovery rate: a practical and powerful approach to multiple testing. Journal of the Royal Statistical Society. 1995, 57: 289-300.

20. Dunwell TL, Hesson LB, Pavlova T, Zabarovska V, Kashuba V, Catchpoole D, Chiaramonte R, Brini AT, Griffiths M, Maher ER, Zabarovsky E, Latif F. Epigenetic analysis of childhood acute lymphoblastic leukemia. Epigenetics. 2009; 4(3):185-93.

21. Kandimalla R, van Tilborg AA, Kompier LC, Stumpel DJ, Stam RW, Bangma CH, Zwarthoff EC. Genome-wide analysis of $\mathrm{CpG}$ island methylation in bladder cancer identified TBX2, TBX3, GATA2, and ZIC4 as pTa-specific prognostic markers. Eur Urol. 2012; 61(6):1245-56.

22. Davis AJ, Yan Z, Martinez B, Mumby MC. Protein phosphatase $2 \mathrm{~A}$ is targeted to cell division control protein 6 by a calcium-binding regulatory subunit. J Biol Chem. 2008; 283(23):16104-14.

23. Ornitz $D M$, Itoh $N$. The Fibroblast Growth Factor signaling pathway. Wiley Interdiscip Rev Dev Biol. 2015; 4(3):215-66.

24. Li H, Du Y, Zhang D, Wang LN, Yang C, Liu B, Wang WJ, Shi L, Hong WG, Zhang L, Yang YX. Identification of novel DNA methylation markers in colorectal cancer using MIRA-based microarrays. Oncol Rep. 2012; 28(1):99-104.

25. Bhushan A, Singh A, Kapur S, Borthakar BB, Sharma J, Rai AK, Kataki AC, Saxena S. Identification and Validation of Fibroblast Growth Factor 12 Gene as a Novel Potential Biomarker in Esophageal Cancer Using Cancer Genomic Datasets. OMICS. 2017; 21(10):616-631.

26. Oleinik NV, Krupenko NI, Krupenko SA. Epigenetic Silencing of ALDH1L1, a Metabolic Regulator of Cellular Proliferation, in Cancers. Genes Cancer. 2011; 2(2):130-9.

27. Fitzgerald TL, Rangan S, Dobbs L, Starr S, Sigounas $G$. The impact of Aldehyde dehydrogenase 1 expression on prognosis for metastatic colon cancer. $J$ Surg Res. 2014; 192(1):82-9.

28. Tam KJ, Dalal K, Hsing M, Cheng CW, Khosravi S, Yenki P, Tse C, Peacock JW, Sharma A, Chiang YT,
Wang Y, Cherkasov A, Rennie PS, Gleave ME, Ong $C J$. Androgen receptor transcriptionally regulates semaphorin 3C in a GATA2-dependent manner. Oncotarget. 2017; 8(6):9617-9633.

29. Rodriguez-Bravo V, Carceles-Cordon M, Hoshida Y, Cordon-Cardo C, Galsky MD, Domingo-Domenech J. The role of GATA2 in lethal prostate cancer aggressiveness. Nat Rev Urol. 2017; 14(1):38-48.

30. Katsumura KR, Ong IM, DeVilbiss AW, Sanalkumar R, Bresnick EH. GATA Factor-Dependent Positive-Feedback Circuit in Acute Myeloid Leukemia Cells. Cell Rep. 2016; 16(9):2428-41.

31. Kampen KR, Scherpen FJ, Garcia-Manero G, Yang H, Kaspers GJ, Cloos J, Zwaan CM, van den Heuvel-Eibrink MM, Kornblau SM, De Bont ES. EphB1 Suppression in Acute Myelogenous Leukemia: Regulating the DNA Damage Control System. Mol Cancer Res. 2015; 13(6):982-92.

32. Brantley-Sieders DM. Clinical relevance of Ephs and ephrins in cancer: lessons from breast, colorectal, and lung cancer profiling. Semin Cell Dev Biol. 2012; 23(1):102-8.

33. Kholodnyuk ID, Kozireva S, Kost-Alimova M, Kashuba V, Klein G, Imreh $S$. Down regulation of $3 p$ genes, LTF, SLC38A3 and DRR1, upon growth of human chromosome 3-mouse fibrosarcoma hybrids in severe combined immunodeficiency mice. Int J Cancer. 2006; 119(1):99-107.

34. Anedchenko EA, Dmitriev AA, Krasnov GS, Kondrat'eva TT, Kopantsev EP, Vinogradova TV, Zinov'eva MV, Zborovskaia IB, Polotskiü BE, Sakharova OV, Kashuba VI, Zabarovskiü ER, Senchenko $V N$. [Down-regulation of RBSP3/CTDSPL, NPRL2/G21, RASSF1A, ITGA9, HYAL1 and HYAL2 genes in non-small cell lung cancer]. $\mathrm{Mol}$ Biol (Mosk). 2008; 42(6):965-76.

35. Loginov VI, Dmitriev AA, Senchenko VN, Pronina IV, Khodyrev DS, Kudryavtseva AV, Krasnov GS, Gerashchenko GV, Chashchina LI, Kazubskaya TP, Kondratieva TT, Lerman MI, Angeloni D, Braga EA, Kashuba VI. Tumor Suppressor Function of the SEMA3B Gene in Human Lung and Renal Cancers. PLoS One. 2015; 10(5):e0123369.

36. Rudenko EE, Gerashchenko GV, Lapska YV, Bogatyrova OO, Vozianov SO, Zgonnyk YM, Kashuba VI. 
Genetic and epigenetic changes of GPX1 and GPX3 in human clear-cell renal cell carcinoma. Biopolym Cell. 2013; 29(5):395-401.

37. Rudenko E, Kondratov O, Gerashchenko G, Lapska Y, Kravchenko S, Koliada O, Vozianov S, Zgonnyk Y, Kashuba $V$. Aberrant expression of selenium-containing glutathione peroxidases in clear cell renal cell carcinomas. Exp Oncol. 2015; 37(2):105-10.

\section{Генетичні та епігенетичні порушення} хромосоми 3 людини, визначені за допомогою NotI-мікропанелей в сімох локалізаціях епітеліальних злоякісних пухлин

\section{Г. В. Геращенко, В. В. Гордіюк, В. І. Кашуба}

Мета: Знайти загальні та специфічні генетичні / епігенетичні зміни хромосоми людини 3 , за допомогою NotI-мікропанелей у епітеліальних новоутвореннях семи різних локалізацій. Методи: Було використано методи дескриптивної статистики для порівняльного аналізу даних NotI-мікропанелей у семи локалізаціях злоякісних пухлин. Результати. Порівняльний аналіз даних NotI-мікропанелей показав значні зміни / метилування 74 генів / локусів у семи локалізаціях раку (товстої кишки, яєчників, нирок, легенів, молочних залоз, шийки матки, передміхурової залози). П'ять генів мають зміни у всіх 7 типах раку (FOXP1, LRRC3B, NKiRAS1, RBSP3, ZIC4). Вони були в основному 3 3 p14-3p24 регіону. П'ятнадцять генів мають делецію / метилювання в 6 та 5 локалізаціях раку. Серед них гени/локуси розташовані приблизно у 3p12-3p26 регіоні (ITGA9, GORASP1, IQSEC1, CGGBP1, NBEAL2, $V H L$ ), 3q13-3q28 регіоні (PPP2R3A, FGF12, ALDH1L1, GATA2, PLCL2). Двадцять два гени з 74 мають зміни тільки в одній локалізації раку. Переважна кількість їх (13 генів / локусів) зустрічається для раку передміхурової залози. Це може свідчити про специфічні механізми канцерогенезу передміхурової залози, які відрізняються від інших локалізацій.Висновки: Аналіз даних NotI-мікропанелей 3-ї хромосоми людини виявив ряд як загальних генетичних/епігенетичних порушень, так і пухлино-специфічні зміни.

Кл юч о в і сл о в а: NotI-мікропанелі, рак товстої кишки, рак яєчників, рак нирки, рак легенів, рак шийки матки, рак молочної залози, рак передміхурової залози, гени-супресори росту пухлин, метилювання, делеція, хромосома 3 людини.

\section{Генетические и эпигенетические изменения} хромосомы 3 человека, определённые с помощью NotI-микропанелей в семи локализациях эпителиальных злокачественных опухолей

А. В. Геращенко, В. В. Гордиюк, В. И. Кашуба

Цель: Установить общие и специфичные для опухолей генетические / эпигенетические изменения хромосомы 3 человека с помощью NotI-микропанелей в эпителиальных новобразованиях при семи различных локализациях. Методы: Были использованы методы дескриптивной статистики для сравнительного анализа данных NotI-микропанелей в семи локализациях злокачественых опухолей. Результаты. Анализ NotIмикропанелей показал значительные изменения делеции / метилирования 74 генов / локусов в семи локализациях рака (толстой кишки, яичника, почек, легких, груди, шейки матки, предстательной железы). Пять генов имеют изменения во всех 7 типах рака (FOXP1, LRRC3B, NKiRAS1, RBSP3, ZIC4). Они были в основном из региона $3 \mathrm{p} 14-3 \mathrm{p} 24$. Пятнадцать генов имеют делецию / метилирование в 6 и 5 локализациях рака. Среди них есть в регионе 3p12-3p26 (ITGA9, GORASP1, IQSEC1, CGGBP1, NBEAL2, VHL), в пределах 3q133q28 региона (PPP2R3A, FGF12, ALDH1L1, GATA2, $P L C L 2)$. Двадцать два гена из 74 имеют изменения только в одной локализации рака. Преобладающее число из них (13 генов / локусов) обнаружено для рака предстательной железы. Это может указывать на конкретные механизмы канцерогенеза предстательной железы, которые отличаются от других локализаций. Выводы. Анализ данных NotI-микропанелей 3-й хромосомы человека выявил ряд как общих генетических/ эпигенетических нарушений в семи локализациях рака, так и опухоль-специфические изменения.

Кл юч е в ы е с л о в а: NotI-микропанели, рак толстой кишки, рак яичников, рак почки, рак легких, рак шейки матки, рак молочной железы, рак предстательной железы, гены-супрессоры роста опухолей, метилирование, делеция, хромосома 3 человека.

Received 13.04.2018 